\title{
EVALUASI PROGRAM BURSA KERJA KHUSUS (BKK) SMK DI KABUPATEN BEKASI
}

\section{Sumarno}

Universitas Negeri Jakarta

Wardani Rahayu

Universitas Negeri Jakarta
Alamat Korespondensi

Jl. Pemuda 2, No. 36, Rawamangun,

Jakarta Timur, DKI Jakarta Indonesia

e-mail:

marnokim@gmail.com

\section{ABSTRACT}

Each vocational high school in Regency of Bekasi has a Special Job Fair (BKK). The main function of BKK is to channeling the workforce of graduates. Evaluation of this program used the discrepancy model from Provus. The implementation consists of 4 stages: Design, Installation, Process, and Product. This research uses qualitative methods that produce descriptive data. The purpose of this study to determine the gap between the standard set by actual facts that occur. Data were collected by questionnaire instrument, interview, documentation, and observation. The data analysis determines each component with very inappropriate categories, not appropriate, appropriate, and very appropriate. The highest gap in the design phase lies in aspects of implementation guidelines, resources at the installation and reporting stages of the product phase, this is because BKK management is unaware of technical guidance due to lack of socialization from local Manpower Office. Socialization is not optimal due to lack of manpower of the coach/guides from the labor agencies. The best aspect of conformity is at the stage of the process, this is due to some activities integrated with the activities of street vendors. The average result is according to the standard, the decision of the program is continued with the recommendation of improvement on some components.

\section{Keywords}

Program evaluation of Discrepancy model, BKK SMK.

\begin{abstract}
ABSTRAK
Setiap SMK di Kabupaten Bekasi memilki Bursa Kerja Khusus (BKK). Fungsi utama BKK adalah menyalurkan tenaga kerja lulusannya. Evaluasi terhadap program ini menggunakan model kesenjangan (discrepancy) dari Provus. Pelaksanaannya terdiri dari 4 tahapan, yaitu: Desain, Instalasi, Proses, dan Produk. Penelitian ini menggunakan metode kualitatif yang menghasilkan data deskriptif. Tujuan penelitian ini untuk mengetahui kesenjangan antara standar yang ditetapkan dengan fakta aktual yang terjadi. Data dikumpulkan dengan instrumen angket, wawancara, dokumentasi, dan observasi. Analisis data menentukan setiap komponen dengan kategori sangat tidak sesuai, tidak sesuai, sesuai, dan sangat sesuai. Kesenjangan tertinggi tahap desain terdapat pada aspek pedoman penyelenggaraan, sumber daya pada tahap instalasi dan pelaporan pada tahap produk, hal ini terjadi karena pengurus BKK tidak mengetahui petunjuk teknis akibat kurangnya sosialisasi dari Disnaker setempat. Sosialisasi tidak optimal karena kurangnya tenaga Pembina/pemandu dari instansi ketenagakerjaan. Aspek paling baik tingkat kesesuaiannya ada pada tahap proses, hal ini disebabkan beberapa kegiatan terintegrasi dengan kegiatan PKL. Rata-rata hasilnya adalah sesuai standar, keputusannya program dilanjutkan dengan rekomendasi berupa perbaikan pada beberapa komponen.
\end{abstract}

\footnotetext{
Kata kunci

Evaluasi program model Discrepancy, BKK SMK.
} 


\section{Pendahuluan}

Data BPS Kabupaten Bekasi menunjukkan terdapat sebanyak 89I industri, dan ini masih angka sementara karena jumlah sebenarnya dapat lebih dari data yang tercatat. Pembangunan industri masih terus dilakukan hingga saat ini terutama di daerah Deltamas perbatasan dengan Kabupaten Karawang. Selain jumlah lapangan kerja yang luas, upah yang besar dan dekat dengan ibukota menjadi salah satu daya tarik para pencari kerja untuk datang ke wilayah ini.

Pada tahun 2013 rasio jumlah SMA : SMK di Kabupaten Bekasi sudah mencapai angka sebesar 96 : I35 atau jika angka tersebut dituliskan dalam bentuk persen menjadi 29,69\%: 70,31\%. Sebanyak I35 SMK yang tersebar di 23 kecamatan mengakibatkan Kabupaten Bekasi menghasilkan ribuan pencari kerja setiap tahunnya. Jika ditambah dengan pendatang yang jumlahnya lebih banyak maka angkatan kerja mungkin tumbuh lebih cepat dari pertumbuhan lapangan kerja.

Tingginya permintaan dan penawaran tenaga kerja dijadikan peluang bisnis oleh beberapa pihak untuk menjual jasa dalam menyalurkan tenaga kerja, yang seringkali tidak menguntungkan bagi pihak pencari kerja. Maraknya penyalur tenaga kerja yang tidak memenuhi harapan para pencari kerja mendorong sekolah-sekolah khususnya SMK untuk membantu para alumninya dalam mendapatkan pekerjaan. Informasi pekerjaan disampaikan melalui media sosial atau melalui bursa kerja yang ada di sekolah.

Bursa kerja yang ada di sekolah biasanya hanya menyalurkan lulusan dari sekolah tersebut sehingga lebih dikenal dengan nama Bursa Kerja Khusus (BKK). Hal ini tentunya menimbulkan pertanyaan besar karena lulusan SMK yang sudah dibekali keterampilan tertentu dan hampir semua SMK di Kabupaten Bekasi sudah memiliki Bursa Kerja Khusus (BKK) yang berperan dalam mengarahkan dan menyalurkan lulusannya ke dunia kerja. Namun jumlah penganggurannya masih cukup tinggi. Apakah ada yang kurang sesuai dengan BKK? Tidak ada yang tahu, karena belum ada peneliti yang mengevaluasi program ini.

Eksistensi BKK di SMK bukan sebagai lembaga bisnis yang menjalankan usahanya untuk mencari keuntungan namun BKK juga bukan panti sosial yang dibiayai oleh donator dalam mengoperasikan segala kegiatannya. Keberadaan BKK dari setiap SMK akan mempengaruhi keterserapan lulusannya ke dunia kerja yang relevan. BKK yang bekerja dengan baik akan dapat melaksanakan programprogram yang menjadi kewajiban dan program lain yang telah direncanakan, memiliki relasi dengan perusahaan atau industri yang banyak sehingga tempat penyaluran lulusannya menjadi lebih luas dan dapat mengurangi masa tunggu lulusan untuk mendapatkan pekerjaan. Selain itu dapat memberikan bimbingan karir dengan baik kepada siswa maupun lulusannya, sehingga siswa dapat memilih dan memiliki pengetahuan mengenai karir serta lebih siap untuk memasuki dunia kerja. Cronbach (1963), Alkin (1969), dan Stufflebeam (197I), dalam Djudju Sudjana (2014:19), menjelaskan bahwa evaluasi adalah kegiatan untuk mengumpulkan, memperoleh, dan menyediakan informasi bagi pembuatan keputusan. Menurut Arikunto (20I4:2), "Evaluasi adalah kegiatan untuk mengumpulkan informasi tentang bekerjanya sesuatu yang selanjutnya informasi tersebut digunakan untuk menentukan alternatif yang tepat dalam mengambil sebuah keputusan". Ada kesamaan definisi dari Djudju Sudjana dan Arikunto, yaitu: proses pengumpulan informasi dan langkah pengambilan keputusan.

Definisi yang hampir sama namun ada sedikit perluasan dikemukakan oleh National Study Commite on Evaluation dari UCLA dalam Eko Putro Widoyoko (2014:4) bahwa: "Evaluation is the process of the decision of concern, selecting appropriate information and collecting and analizing information on order the report summary data useful to decision makers in selecting among alternatives".

Maksud dari pernyataan tersebut adalah: Evaluasi merupakan suatu proses atau kegiatan pemilihan, pengumpulan, dan analisis serta penyajian informasi yang dapat digunakan sebagai dasar pengambilan keputusan serta penyusunan program selanjutnya. Perluasan pengertiannya terletak pada penyusunan rencana selanjutnya setelah keputusan diambil.

Kath Aspinwall (1992:2) mengemukakan definisi evaluasi sebagai berikut: "Evaluation is part of decision making process. It is making judgement about 
the worth of an activity through systematically and openly collecting analyzing information and obout it and relating this to explicit objectives, criteria, and values"

Pengertian dari pernyataan di atas adalah bahwa evaluasi merupakan bagian dari proses pengambilan keputusan. Hal tersebut mencakup pembuatan keputusan tentang kebaikan atau manfaat dari suatu aktivitas dengan cara pengumpulan informasi yang dianalisis secara sistematis dan terbuka serta kaitannya dengan tujuan-tujuan, kriteria dan nilainilai. Demikian juga dalam buku edisi terbarunya Wirawan (2016:10) mendefinisikan "Riset evaluasi atau evaluasi sebagai riset untuk mengumpulkan, menganalisis dan menyajikan informasi yang bermanfaat mengenai obyek evaluasi, menilainya dan membandingkannya dengan indikator evaluasi dan hasilnya dipergunakan untuk mengambil keputusan mengenai nilai dan manfaat objek evaluasi”.

Dari dua pendapat, yaitu: Kath Aspinwall dan Wirawan memilki kesamaan definisi evaluasi, yaitu: berupa pengumpulan informasi, analisis data, kriteria objek, keputusan, dan nilai atau manfaat tentang obyek yang dievaluasi.

Sebagai orang pertama yang mengemukakan gagasan Dicrepancy Evaluation Malcolm M. Provus (1969:13) menjelaskan bahwa evaluasi pada tingkat yang paling sederhana dapat dilihat sebagai perbandingan antara kinerja dan standar. Muljono dan Djaali (2004:I) juga mengemukakan pendapat yang sejalan dengan pernyataan di atas bahwa evaluasi adalah proses menilai sesuatu berdasarkan kriteria atau tujuan yang telah ditetapkan, yang selanjutnya dengan pengambilan keputusan atas objek yang dievaluasi.

Berdasarkan pengertian dari para ahli yang dikemukakan di atas maka dalam penelitian ini dapat didefinisikan bahwa evaluasi adalah kegiatan untuk mengambil keputusan dan rekomendasi atas nilai dan manfaat dari suatu objek melalui pengumpulan informasi. Pengertian program secara umum adalah suatu rencana untuk melakukan sesuatu kegiatan dalam suatu organisasi untuk mencapai tuiuan yang telah ditetapkan.
Arikunto dan Abdul Jabar (2010:4) mendefinisikan program dalam dua bentuk, yakni: program yang berlangsung dalam waktu singkat, dan program yang dalam pelaksanaannya memerlukan waktu lama untuk melihat hasilnya. Namun keduanya memiliki kesamaan, yakni: merupakan suatu unit atau kesatuan kegiatan. Pendapat yang berbeda dari definisi di atas menyatakan bahwa program adalah suatu rancangan (kegiatan) yang khusus dibentuk untuk tujuan tertentu, terukur, dan obyektif. Pernyataan ini disampalkan oleh Spaulding (2008:5) dalam bukunya Program Evaluation in Practice: Core Concepts and Examples for Discussion and Analysis yang menyatakan: "a program is a set of specific activities designed for an intended purpose, with guantifiable goals and objectives".

Terdapat 3 pengertian penting dan perlu ditekankan dalam menentukan program Arikunto dan Abdul Jabar (2010:3), yaitu: (I) realisasi atau implementasi suatu kebijakan, (2) terjadi dalam waktu relatif lama bukan kegiatan tunggal tetapi jamak berkesinambungan, dan (3) terjadi dalam organisasi yang melibatkan sekelompok orang. Jika membatasi pengertian "program" sebagai kegiatan yang direncanakan, maka program tersebut tidak lagi disebut demikian jika kegiatannya sudah selesai dilaksanakan.

Dari paparan di atas diperoleh definisi tentang program sebagai suatu kegiatan sistematis, berkesinambungan dalam satu kesatuan (unit), serta memiliki tujuan yang ingin dicapai yang terencana dan terukur. Artinya, program bukan kegiatan tunggal, atau suatu kegiatan sederhana yang tidak terdiri dari beberapa komponen dalam satu unit.

Posavac (1985:6) menyatakan bahwa evaluasi program adalah kumpulan metode, keterampilan, dan kepekaan yang diperlukan untuk menentukan apakah masyarakat membutuhkan sebuah program pelayanan, dan memperhatikan apakah kondisi lingkungannya memungkinkan untuk terlaksananya kegiatan tersebut, kemudian apakah program yang diberikan itu cukup untuk memenuhi kebutuhan, apakah aplikasi layanan yang 
diberikan seperti yang direncanakan dan apakah pelayanan tersebut benar-benar membantu kesulitan masyarakat setempat.

Bursa kerja adalah suatu lembaga yang mempunyai fungsi untuk merekrut tenaga kerja baru dan kemudian disalurkan atau ditempatkan ke dunia kerja atau dunia industri sesuai dengan perjanjian yang telah disepakati sebelumnya. Penyelenggaraan bursa kerja merupakan upaya untuk mendekatkan antara peluang kerja yang ada dengan SDM yang tersedia. Demikian halnya sebagaimana yang dikemukakan oleh Kementerian Transmigrasi (2008:4) pada ayat I pasal 39 menyatakan bahwa "bursa kerja adalah tempat pelayanan kegiatan penempatan tenaga kerja."

Departemen Tenaga Kerja dan Transmigrasi Depnakertrans RI, Dirjen Binapenta (2008:4) menyatakan bahwa "Bursa Kerja Khusus yang selanjutnya disebut BKK adalah Bursa Kerja yang berada di Lingkungan Satuan Pendidikan Menengah di Satuan Pendidikan Tinggi dan di Lembaga Pelatihan Kerja".

Model evaluasi yang dipilih pada penelitian ini adalah model evaluasi discrepancy dari Provus, dengan pendekatan evaluasi berbasis tujuan, yaitu: objectives-oriented approaches menurut Fitzpatrick dkk. Kaufman \& Thomas (1980:127) menyatakan model penelitian evaluasi ini berorientasi pada pengukuran kesenjangan di dalam pelaksanaan program. Pendapat lain mengenai model penelitian evaluasi ini yang senada dengan pendapat di atas, disampaikan oleh Madaus, Scriven \& Stufflebeam (1986:80), yaitu: “...evaluation as being a matter of making judgements about the worth or adequacy of an object based upon $D$ (Discrepancy) information between S (Standard) and P (Performance)". Pendapat tersebut menjelaskan bahwa evaluasi sama dengan kegiatan pembuatan penilaian tentang kelayakan atau kecukupan suatu obyek berdasarkan informasi kesenjangan $(D)$ antara standar $(S)$ dan kinerja $(P)$.

Menurut Wirawan (2016: I53) kelebihan model kesenjangan adalah: "(I) Model evaluasi ketimpangan sederhana dan mudah dilaksanakan. Model ini hanya membandingkan kinerja program dengan standar kinerja yang juga didefinisikan dan diformulasikan, (2) Model ini memperkenalkan konsep manajemen informasi, proses, ruang kelas, dan pentingnya pembangunan pangkalan data yang menghubungkan karakteristik siswa dan kinerja para siswa, (3) Model ini mengembangkan hubungan yang terus menerus antara staf evaluator permanen dan perencana dan pengembangan program, dan (4) Model ini menggunakan evaluasi formatif untuk merevisi dan mengoreksi program untuk mengarahkan kembali pada awal pengembangan dan instalasi program."

Kelemahan dari model evaluasi ketimpangan antara lain: (I) Untuk melaksanakan model ini memerlukan waktu yang panjang karena pertanyaan yang harus dijawab secara berurutan untuk sampai kepada keputusan. Salah satu tujuan dari pertanyaan-pertanyaan adalah untuk mengikutsertakan staf program dalam proses evaluasi (2) Taksonomi yang diidentifikasi sebagai suatu standar untuk definisi dari program merupakan daftar kategori. Standar yang sesungguhnya seperti jumlah dan waktu pelatihan para guru harus dikembangkan di tempat lain.

\section{Metode Penelitian}

Tujuan umum dari evaluasi program ini adalah untuk mengetahui bagaimana sebuah program BKK SMK di Kabupaten Bekasi dapat diimplementasikan, sejauh mana terlaksananya program, ketercapaian tujuan program seperti yang ditetapkan, dan untuk mengetahui kendala dalam implementasi program tersebut (Arikunto, 2009:7)

Metode yang digunakan dalam penelitian ini adalah metode kualitatif, yang menghasilkan data deskriptif berupa tulisan, ucapan, dan perbuatan yang diamati dari alumni, pengelola BKK, guru produktif, dan instansi terkait lainnya. Dilaksanakan dalam suatu setting konteks tertentu yang dikaji dari sudut pandang yang utuh, komprehensif, dan holistik (Jusuf Soewadji, 2012:52), yang alamiah dan dengan memanfaatkan berbagai metode ilmiah (Moleong, 2006:6), dengan metode pengumpulan data melalui observasi, wawancara atau penelaahan dokumen dan angket.

\section{Hasil Penelitian dan Pembahasan}

Deskripsi data hasil evaluasi kesenjangan dari semua tahapan yang meliputi desain, instalasi, 
proses dan produk ditampilkan pada diagram di bawah ini:

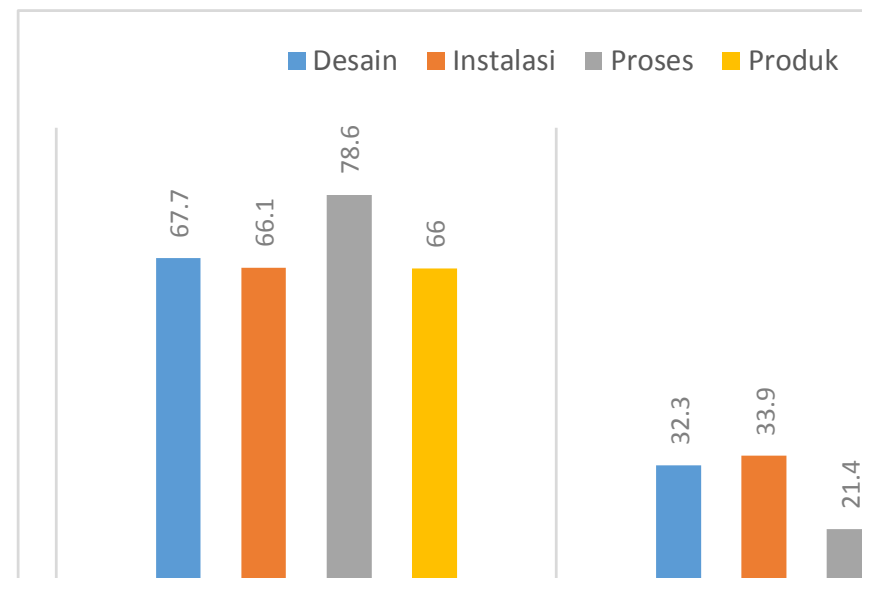

Berdasarkan tampilan diagram di atas terlihat bahwa hampir semua tahapan nilai kesenjangan berkisar antara $30 \%$ sampai dengan $40 \%$, kecuali tahapan proses yang kesenjangannya paling kecil, yaitu: $21,4 \%$. Ditinjau dari aspek evaluasi, maka ada 3 (tiga) aspek yang terbesar kesenjangannya, yaitu: pada tahapan desain aspek pedoman penyelenggaraan $57 \%$, pada tahapan instalasi aspek sumber daya manusia $57 \%$, dan pada tahap produk adalah aspek pelaporan $60 \%$. Komponen penyebab tingginya kesenjangan akan dibahas secara rinci pada pembahasan kesenjangan setiap komponen di bawah ini.

Peneliti melakukan penggalian informasi tentang sekolah mana saja yang menyusun pedoman pelaksanaan program BKK, dan hasilnya tidak ada satupun yang membuat pedoman pelaksanaan. Alasan tidak membuat pedoman pelaksanaan program karena tidak mengetahui petunjuk teknis. Ketika peneliti menunjukkan petunjuk teknis yang dikeluarkan Binapenta semua pengurus BKK mengatakan tidak memiliki dan baru pertama melihatnya. Hasil penggalian informasi lebih lanjut tentang alasan pengurus tidak memiliki petunjuk teknis dari Binapenta adalah karena pengurus BKK tidak pernah mendapatkan sosialisasi petunjuk teknis pendirian BKK di SMK. Dalam hal ini peneliti memaklumi karena peneliti juga mendapatkan Petunjuk Teknis Pendirian Bursa Kerja Khusus dari Direktorat Pengembangan SMK.
Ketika peneliti mencari di internet, file tersebut tidak ditemukan.

Faktor yang menjadi penyebab tidak dilaksanakan sosialisasi Petunjuk teknis pendirian BKK adalah tidak adanya tenaga pemandu yang terlatih di Disnaker Kabupaten. Padahal dalam petunjuk teknis tercantum bahwa Disnaker harus memilki tenaga pemandu BKK yang terlatih. Pegawai yang menangani BKK ada tetapi hanya satu orang dengan tugas dan tanggung jawab selain BKK yang lebih banyak. Hampir setiap tahun petugas yang menangani BKK mengalami rotasi jabatan. SMK di Kabupaten Bekasi berjumlah 135 sekolah yang semuanya memiliki BKK. Setiap BKK minimal memiliki 6 (enam) orang pengurus sebagai tenaga teknis. Fakta aktual yang ada di Kabupaten Bekasi, tidak ada satupun BKK yang memenuhi kriteria tersebut. Umumnya di SMK hanya memiliki I orang pengurus BKK sebagai ketua merangkap anggota, kecuali di SMKN I Cikarang Barat ada Ketua BKK yang dibantu satu orang tenaga kependidikan sebagai staf BKK.

Faktor penyebab tidak terpenuhinya jumlah pengurus adalah sebagai berikut: (a) Guru sulit dijadikan sebagai tenaga teknis BKK, karena sangat banyaknya tugas yang dibebankan kepada guru dan padatnya aktifitas yang harus dikerjakan sebagai pengurus BKK. (b) menggunakan tenaga kependidikan sebagai pengurus BKK tidak dapat dilakukan karena minimnya anggaran yang dialokasikan untuk BKK.

Komponen pertama pelaporan adalah BKK menyusun laporan kegiatan setiap bulan, triwulan, dan tahunan. Komponen kedua pelaporan adalah laporan disampaikan kepada Dinas Tenaga Kerja Kabupaten Bekasi dengan format dan lampiran sesuai Petunjuk teknis. Fakta aktualnya sebagian besar BKK tidak menyampaikan laporan dan sebagian kecil membuat laporan yang disampaikan kepada Disnaker Kabupaten Bekasi, tetapi formatnya tidak sesuai dengan format yang ada pada petunjuk teknis. Komponen kedua memperoleh kategori sangat tidak sesuai dan komponen pertama tidak sesuai. Kesenjangan yang terjadi diakibatkan ketidaktahuan pengurus terhadap petunjuk teknis pelaporan. 
Hasil analisis terhadap tiga standar komponen yang menjadi penyebab terjadinya kesenjangan dapat diatasi dengan pengadaan tenaga pembina/pemandu yang kompeten pada Disnaker Kabupaten dengan jumlah yang proporsional sesuai jumlah SMK yang terdapat di kabupaten. Demikian halnya dengan tenaga pembina dari provinsi.

Kesenjangan paling kecil terdapat pada tahapan proses. Proses pelaksanaan program secara umum terintegrasi dengan kegiatan PKL, sehingga komponen pada sebagian besar aspek terlaksana sesuai dengan standar petunjuk teknis walaupun dilaksanakan bukan oleh pengurus BKK.

\section{Daftar Pustaka}

Arikunto Suharsimi dan Cepi Safruddin Abdul Jabar, Evaluasi Program Pendidikan Pedoman Teoritis Praktis Bagi Mahasiswa dan Praktisi Pendidikan, Jakarta: Bumi Aksara, 2009.

Arikunto Suharsimi dan Abdul Jabar, Evaluasi Program Pendidikan; Pedoman Teoritis Praktis bagi Mahasiswa dan Praktisi Pendidikan Jakarta: Bumi Aksara, 2010.

Arikunto Suharsimi dan Cepi S. Abdul Jabar, Evaluasi Program Pendidkan: Pedoman Teoritis Praktis Bagi Mahasiswa dan Praktisi Pendidikan, eds. Kedua, Cetakan kelima, Jakarta: Bumi Aksara, 2014.

Dean T. Spaulding, Program Evaluation in Practice: Core Consepts and Examples for Discussion and Analysis (San Francisco: Joseey Wiley \& Sons, Inc. 2008.

Djaali dan Pudji Muljono, Pengukuran Dalam Bidang Pendidikan Jakarta: Program Pascasarjana UNJ, 2004.

Depnakertrans RI, Kep-I3 I/DPPTKDN/XI/2004, tentang: "Petunjuk Teknis Bursa Kerja Khusus" Jakarta Dirjen Binapenta, 2004.
Depnakertrans RI, Kep.No,250/Men/XII/2008, tentang: "Kasifikasi dan Karakteristik Data dari Jenis Informasi Ketenagakerjaan” Jakarta, 2008.

G. F. Madaus, M. S. Scriven, \& D. L. Stufflebeam, Evaluation models: Viewpoints on Educational and Human Services Evaluation, Norwell: Kluwer Academic Publisher, 1986.

J. Moleong Lexy, Metodologi Penelitian Kualitatif Bandung: Remaja Rosdakarya, 2006.

J. Posavac Emil dan Raymond G. Carey, Program Evaluation: Methods and Cas Studies New Kersey: Prentice-Hall Inc., 1985.

Kath Aspinwall, Managing Evaluation in Education: a Development Approach London: Routledge, 1992.

Provus Malcolm M., The Discrepancy Evaluation Model: An Approach to Local Program Improvement and Development Pitshburgh: Spons Agency Office of Education, 1969.

R. Kaufman, \& S. Thomas, Evaluation without fear, New York: New View Points. 1980.

Soewadji Jusuf, Pengantar Metodologi Penelitian Jakarta: Mitra Wacana Media, 2012.

Sudjana Djudju, Evaluasi Program Luar Sekolah Bandung: PT. Remaja Rosdakarya, 20I4.

Widoyoko Eko Putro, Evaluasi Program Pembelajaran Yogyakarta: Pustaka Pelajar, 2014.

Wirawan, Evaluasi: Teori, Model, Metodologi, Standar, Aplikasi dan Profesi Jakarta: Rajawali Pers, 2016. 